\title{
Deep groundwater quality and its suitability for drinking and agricultural purposes, Wadi Baye, Middle Region, Libya
}

\author{
F. A. Swaid \& A. A. Issa \\ Great Man-made River Water Utilization Authority, Libya
}

\begin{abstract}
Assessment of suitability of deep artesian groundwater (Kiklah aquifer) for domestic and agricultural purposes was carried out in the Wadi Baye area; Middle Region, Libya, where, groundwater is the main source for domestic and agricultural activity. Eighteen groundwater samples were collected from different wells, distributed over the Wadi's area. Suitability of groundwater for irrigation purpose was evaluated based on US Salinity diagram, which shows that $89 \%$ of the samples falls in the zone of very high-salinity hazard (C4) and medium-sodium hazard (S2) type. The Wilcox diagram shows that most of the samples (89\%) fall in the category of doubtful to unsuitable for irrigation purposes. The residual sodium carbonate (RSC) and the sodium adsorption ratio (SAR) in groundwater signified good quality. While soluble sodium percentage $(\mathrm{Na} \%)$ indicates water is doubtful for irrigation, permeability index (PI) indicates water is injurious to unsatisfactory for irrigation and the magnesium adsorption ratio (MAR) indicative that $72.2 \%$ of groundwater samples are suitable for irrigation purposes. Overall, the groundwater can be classified with few exceptions as suitable for irrigation under certain conditions such as good management, good drainage system, deep ground to keep soil salt balance and highly salt tolerant plants. However, it is recommended that water drawn from such sources should be purified of excess elements well before being used for drinking and other purposes. Wells numbered as 1, 3, 4, 6 should also be excluded from domestic and drinking uses. Also it is recommended that the water should be not used directly after pumping.
\end{abstract}

Keywords: water quality, Kiklah aquifer, physicochemical parameter, Libyan drinking water standards, salinity hazard. 


\section{Introduction}

Groundwater plays an important role in North African countries' agriculture, drinking and in shaping the countries' economy. A good quality of groundwater can help in the better yield of crops. Water used for irrigation purpose should have certain quality specifications. The suitability of water for irrigation mainly depends upon the tolerance of plants to certain chemical constituents, properties of soils and irrigation practices. Groundwater always contains some amount of constituents dissolved in it. Water containing high concentrations of soluble salts may be harmful for many crops because their presence affects the soil structure, permeability and aeration [1-3]. Hence it is essential to properly evaluate groundwater quality for irrigation purpose. Therefore, the requirement for the assessment of suitability of groundwater resources for drinking and irrigation purposes is becoming increasingly important and this is demonstrated by the relatively large number of recent studies in this field [4, 5]. Generally, the suitability of groundwater for agriculture and domestic purposes largely depends on the site specific quality of the water, with possible temporal variations caused by climatic conditions, as well as the residence time of water within the aquifer materials and anthropogenic activities [6]. In certain conditions, especially where there is accumulation of sodium ions and other ions in the soil structure due to extended use of certain irrigation water, could cause deterioration in the soil physical properties, and thereby results in the decrease of the crop yield. Hence, this work intends to assess the physical and chemical characteristics of the local groundwater resources around the Wadi Baye area in order to determine its suitability for a different purpose such as irrigation and drinking.

\section{The study area}

Wadi Baye area situated $70 \mathrm{Km}$ at west of Sirte city (Northern Libya). It extends from the Hun graben at South Western up to Mediterranean sea at the North, between $15^{\circ} 00^{\prime}-15^{\circ} 56^{\prime} \mathrm{E}$ longitude and $31^{\circ} 00^{\prime}-31^{\circ} 53^{\prime} \mathrm{N}$ latitude, flows from southwest to northeast and covering an area of about $37.3 \mathrm{~km}^{2}[7,8]$, fig. 1 . Depending on De Martonne classification, the study area has been classified as arid or semi-arid region, temperature ranges between $\left(13.8^{\circ} \mathrm{C}\right)$ in January and $\left(26.9^{\circ} \mathrm{C}\right)$ in August. The average annual precipitation decreases from $170 \mathrm{~mm} / \mathrm{yr}$ in north to $50 \mathrm{~mm} / \mathrm{yr}$ in south with the distance away from the coast, and the evaporation increases from $1701 \mathrm{~mm} / \mathrm{yr}$ in north to $2607 \mathrm{~mm} / \mathrm{yr}$ in south, during the last 20 years according to [9].

\subsection{Geology and hydrogeology setting}

The only water resource in Wadi Baye is groundwater with minimal rainfall during wet season, and the most groundwater production is from Kiklah (deep) and Eocene (shallow) aquifers. Kiklah sandstone aquifer is a confined aquifer with groundwater levels above ground surface. Kiklah aquifer is the main current source for domestic and agricultural water supply in many parts of Libyan Middle 
Region and it provides water for the villagers living in the Wadi region. This aquifer is artesian but very deep $(1,210 \mathrm{~m}-1,574 \mathrm{~m})$. The water is slightly mineralized $(1530 \mathrm{mg} / \mathrm{L})$ and at high temperature $\left(>60^{\circ} \mathrm{C}\right)$. The aquifer thickness ranges from $30 \mathrm{~m}$ to $182 \mathrm{~m}$. [10]. Part of this aquifer extends outside the Wadi catchment area where eighteen of productive wells are located within the valley region, fig. 2. The groundwater production has been from naturally overflowing wells. However, Because the groundwater levels have fallen since the mid of 1970 s as a result of groundwater production, only four wells $(3,4,5,6)$ still playing a basic role as a water source in Wadi Baye project to provide water for irrigation and other purposes [10]. In addition, the groundwater level has dropped more than 60 meters since the 1970s in some surrounding wells which are located within the surrounding wadis such as Wadi Zamzam and Wadi Amrah. This decline makes some non-productive wells have been occurred [10].

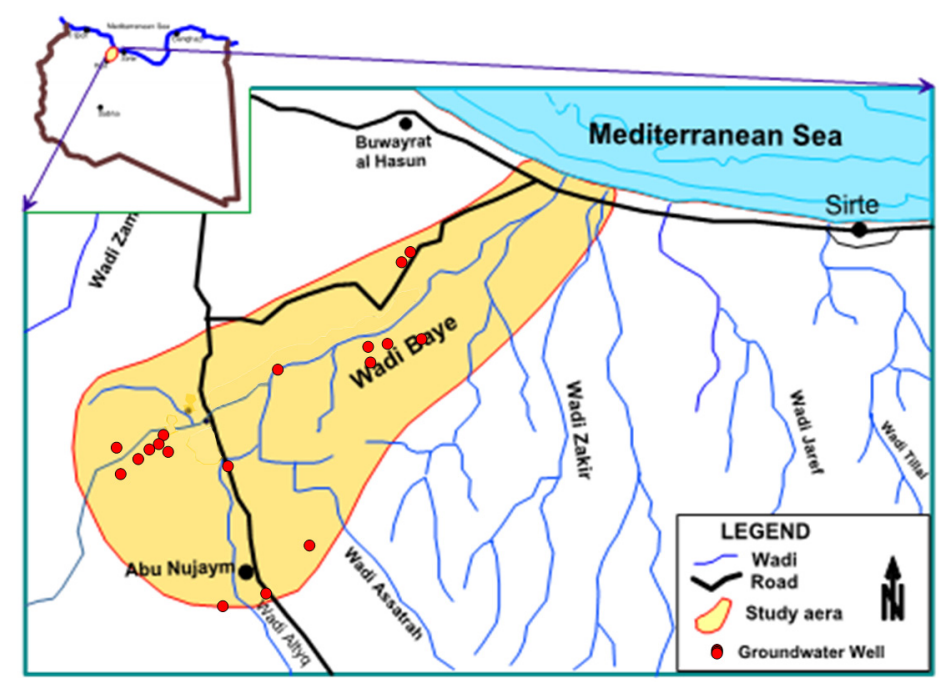

Figure 1: Location map of Wadi Baye area, Northern Libya.

\subsection{Field and laboratory methods}

Ground water samples were collected from eighteen deep groundwater wells in the study area (figs. 1 and 2). Sampling was carried out in October 2010, $\mathrm{pH}$, temperature and electrical conductivity were measured in the field using digital meters immediately after sampling, [10].

Total dissolved solid TDS determined in laboratory by evaporation the water to dryness and weighing the residue [10], total hardness TH was calculated using equation:

$$
\mathrm{TH}=(2.49 \mathrm{Ca}+4.11 \mathrm{Mg})[11]
$$


The major ions (Cations and Anions) were carried out using standard method for water analyses as suggested by [11], table 1, the laboratory work was completed within a few weeks of water samples collections.

Each sample was checked for accuracy by calculating ion-balance (I.B) equal:

$$
\mathrm{I} . \mathrm{B} \%=[(\text { sum cation }- \text { sum anion }) /(\text { sum cation }+ \text { sum anion })] * 100
$$

It was found that the analytical errors of all samples were less than $5 \%$, which ensured the reliability of the chemical data. All these analyzed were measured by the General Water Authority Laboratory, Tripoli [10].

Table 1: Methods used for major ion analysis of ground water samples.

\begin{tabular}{|c|c|c|c|c|c|}
\hline Soluble Ions & Ca and Mg & Na and K & $\mathbf{H C O}_{3}$ & $\mathbf{C l}$ & $\mathbf{S O}_{4}$ \\
\hline Methods & $\begin{array}{c}\text { Titration } \\
\text { using } \\
\text { EDTA }\end{array}$ & $\begin{array}{c}\text { Flame } \\
\text { photometer }\end{array}$ & $\begin{array}{c}\text { Titration } \\
\mathrm{H}_{2} \mathrm{SO}_{4}\end{array}$ & $\begin{array}{c}\text { Titration } \\
\text { using } 0.05 \mathrm{~N} \\
\mathrm{AgNO}_{3}\end{array}$ & $\begin{array}{c}\text { Spectro- } \\
\text { photometer }\end{array}$ \\
\hline
\end{tabular}

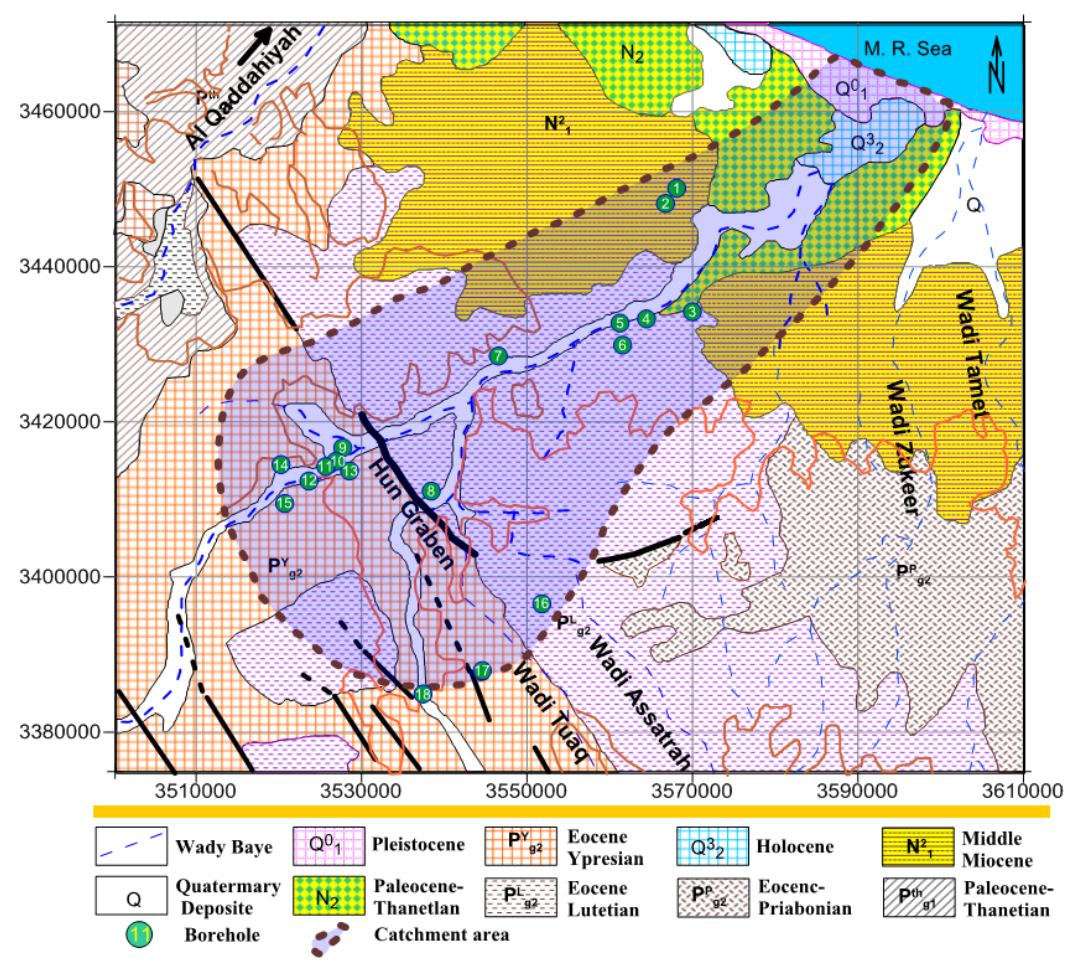

Figure 2: Geological map and wells location of the study area (after [7]). 


\section{Hydrogeochemistry}

Ground water quality assessment; carried out to determine suitability of water samples in terms of domestic and agricultural purposes. The portability of drinking water from domestic well samples is mainly based on recommended permissible limits for certain parameters described in Libyan Standards [12], WHO [13] and US Public Health Service [14].

The data revealed that there were considerable variations in physico-chemical properties of examined samples from the different wells. Temperature of the water samples were ranging from $56-73^{\circ} \mathrm{C}$. Temperature is important to assess the quality of water because of its influence on water chemistry. The rate of chemical reactions generally increases at higher temperature. Groundwater, with higher temperatures can dissolve more minerals from the rocks it is in and will therefore have a higher electrical conductivity (EC) [15]. The $\mathrm{pH}$ of analyzed samples varies from 7.01 to 7.35 ; this indicates that ground water is neutral to alkaline range. In addition, EC of the water samples ranged from 2250 to $4033 \mu \mathrm{S} / \mathrm{cm}$ which revealed a variation in EC. High EC were found in water samples which located near the coast. It has been reported that EC is affected by the presence of TDS and Temperature, high value of EC is correlated with high TDS $\left(r^{2}=0.979\right)$. EC is used as an indicator and classification of salinity. Therefore, high EC means high degree of salinity and an index of the amount of dissolved substances in water [16]. TDS of the water samples ranged from 1451.5 to $2700.9 \mathrm{mg} / 1$ gradually increasing towards the coastal areas as shown in fig. 3 .

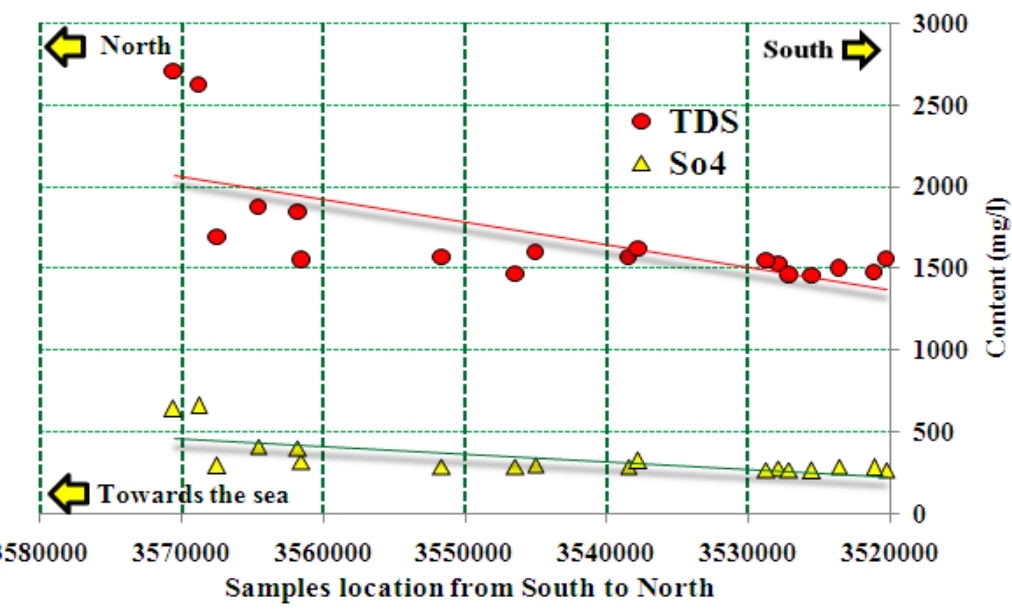

Figure 3: Variation of TDS mg/l and SO4 with distance from South to North.

Total hardness $(\mathrm{TH})$ as $\mathrm{CaCO}_{3} \mathrm{mg} / \mathrm{L}$ of the water samples were ranged between 500.2 to $760.8 \mathrm{mg} / \mathrm{l}$. The TH values of all samples exceeds (WHO) allowable limit. These values of hardness could be occurring as a result of the dissolution of limestone deposit. 
Also, the result show that chloride varied from 399-685 mg/l, the permissible limit for chloride in drinking water is up to $250 \mathrm{mg} / \mathrm{l}$. The result shows that the highest values of $\mathrm{Cl}$ were observed at wells that nearer to the coast. Therefore, increasing in the values of both chlorides and TH near the coast indicated that high values may be caused by water-rock interaction or ancient saline conditions (fig. 4). Therefore, the results are plotted in the Piper [17] Trilinear Diagram (fig. 5). This diagram provides a convenient method to classify and compare groundwater types, based on the ionic composition of different water samples. This diagram reveals that there are two different groundwater types have been identified in the study area. The first is rich in sodium chloride - sulphate $(\mathrm{Cl} \cdot \mathrm{SO} 4-\mathrm{Na})$ water type. The second is rich in calcium sodium sulphate - chloride $(\mathrm{Cl} \cdot \mathrm{SO} 4-\mathrm{Na} \cdot \mathrm{Ca})$ water type, fig. 6 . However, the water type for this aquifer is more complex and can be divided to more than four types.

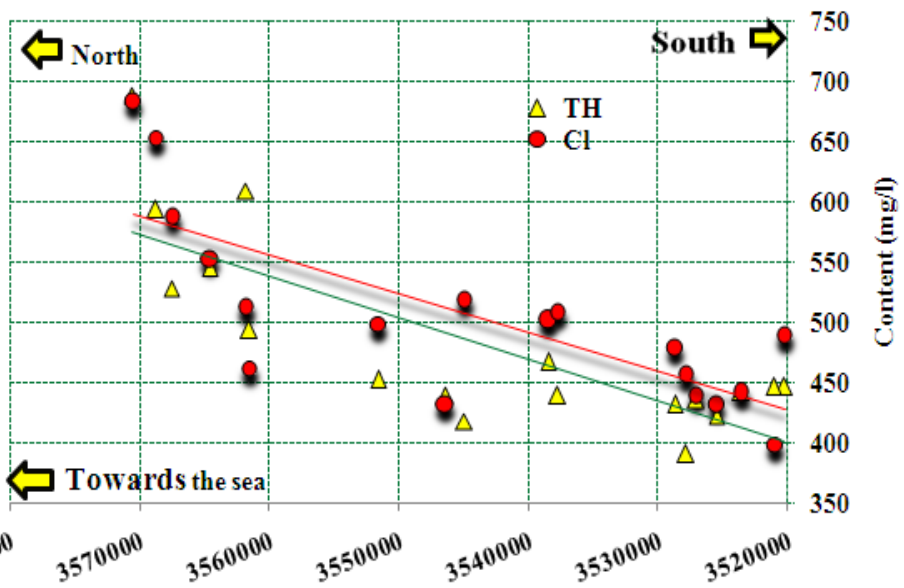

Samples location from South to North

Figure 4: Variation of $\mathrm{Cl} \mathrm{mg/l}$ and $\mathrm{TH}$ with distance from South to North.

Table 2: $\quad$ The summary of the hydrochemical analyses result of ground water samples, after [10].

\begin{tabular}{|c|c|c|c|c|c|c|}
\hline Parameter & TDS mg/l & $\begin{array}{c}\mathrm{CaCO}_{3}^{-} \\
\mathrm{mg} / \mathrm{l}\end{array}$ & $\mathrm{Na}^{+} \mathrm{mg} / \mathrm{l}$ & $\mathrm{K}^{+} \mathrm{mg} / \mathrm{l}$ & & $\begin{array}{l}\mathrm{Mg}^{2+} \\
\mathrm{mg} / \mathrm{l}\end{array}$ \\
\hline Maximum & 2700.86 & 840.29 & 508.0 & 120.0 & & 86.44 \\
\hline Minimum & 1451.5 & 500.18 & 236.0 & 48.0 & & 28.81 \\
\hline Average & 1700.86 & 598.75 & 288.44 & 65.78 & & 66.04 \\
\hline$\overline{\text { Paran }}$ & $\begin{array}{l}\mathrm{Ca}^{2+} \\
\mathrm{mg} / \mathrm{l}\end{array}$ & $\begin{array}{c}\mathrm{HCO}_{3}{ }^{-} \\
\mathrm{mg} / \mathrm{l}\end{array}$ & $\begin{array}{c}\mathrm{Cl}^{-} \\
\mathrm{mg} / \mathrm{l}\end{array}$ & $\begin{array}{c}\mathrm{SO}_{4}{ }^{2-} \\
\mathrm{mg} / \mathrm{l}\end{array}$ & $\mathrm{pH}$ & T.C. \\
\hline Maximum & 216.05 & 468.63 & 684.61 & 658.52 & 7.35 & 73 \\
\hline Minimum & 96.02 & 253.84 & 399.88 & 260.12 & 7.01 & 56 \\
\hline Average & 129.43 & 304.59 & 503.77 & 339.38 & 7.21 & 64.3 \\
\hline
\end{tabular}




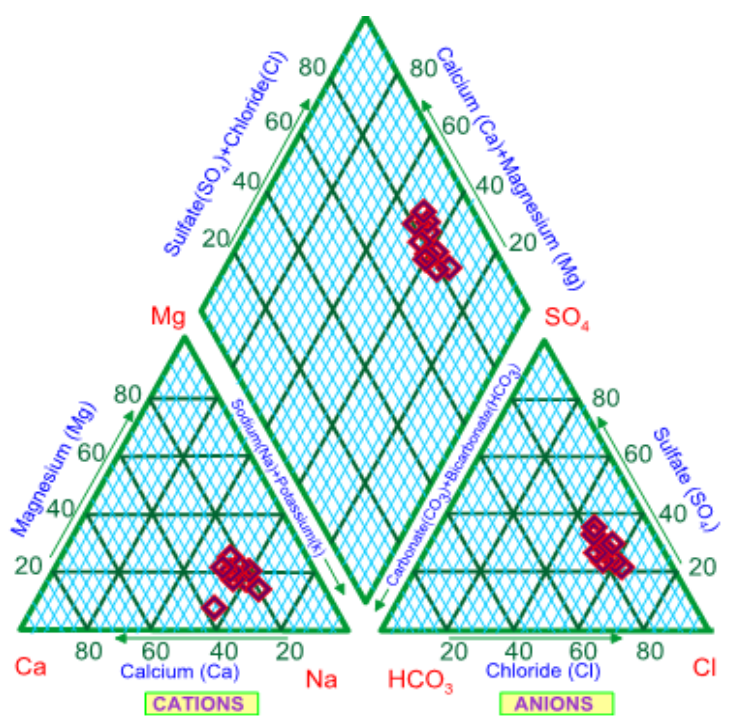

Figure 5: Groundwater sample plotted in Piper diagram.

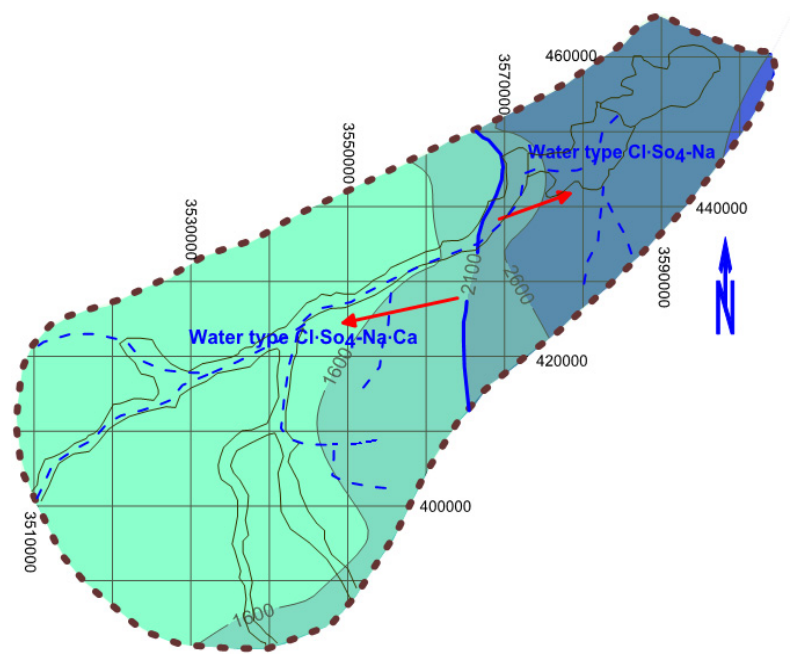

Figure 6: $\quad \mathrm{EC}(\mu \mathrm{S} / \mathrm{cm})$ contour map which represents the distribution of the groundwater types for the deep aquifer.

\subsection{Drinking water quality}

Groundwater quality assessment was carried to determine its suitability in terms of drinking purposes, the hydro chemical analysis of groundwater samples is presented in, table 3 . The physical and chemical parameters of the analytical results of groundwater were compared with [12-14]. 
The concentration of total dissolved solids exceeds the desirable limit of 1000 $\mathrm{mg} / \mathrm{L}$ in all samples. $\mathrm{Na}^{+}$values exceed the desirable limit of $200 \mathrm{mg} / \mathrm{L}$ in all samples. $\mathrm{Cl}^{-}$values exceed the desirable limit of $250 \mathrm{mg} / \mathrm{L}$ in all samples. And also $\mathrm{So}_{4}$ desirable limit of $400 \mathrm{mg} / \mathrm{L}$ in all samples. However, the concentration of $\mathrm{Ca}$, and $\mathrm{K}$ were found few values exceed the desirable limit. While the $\mathrm{Mg}^{2+}$, $\mathrm{HCO}_{3}{ }^{-}$and $\mathrm{pH}$ values were indicative of suitable groundwater for drinking and domestic applications. It is recommended that water drawn from such sources should be purified of excess elements well before being used for drinking and other. It also should be excluded wells numbered as 1,3, 4, and 6 from the domestic and drinking use.

Table 3: GW minimum specifications of Wadi Baye compared with maximum permissible limits prescribed by [12-14].

\begin{tabular}{|c|c|c|c|c|c|}
\hline \multirow[t]{3}{*}{ Parameter } & \multirow{2}{*}{$\frac{\text { Wadi Bayi }}{\text { GW samples }}$} & \multicolumn{3}{|c|}{ Maximum permissible limits } & \multirow{3}{*}{$\begin{array}{c}\text { No of } \\
\text { sample. } \\
\text { over limit }\end{array}$} \\
\hline & & $\begin{array}{c}\text { LDWS } \\
{[12]}\end{array}$ & WHO [13] & U.SEPA [14] & \\
\hline & Min-Max & Maximum & Maximum & Maximum & \\
\hline TDS mg/l & $1452-2701$ & $\begin{array}{l}\text { Up to } \\
1000\end{array}$ & 1000 & 500 & All \\
\hline $\mathrm{pH}$ & $7.01-7.35$ & $6.5-8.5$ & $6.5-9.5$ & - & Nil \\
\hline $\mathrm{K}^{+} \mathrm{mg} / \mathrm{l}$ & $48-53.0$ & 40 & - & 20 & All \\
\hline $\mathrm{Na}^{+} \mathrm{mg} / \mathrm{l}$ & 236- 508 & 200 & 200 & 200 & All \\
\hline $\mathrm{Mg}^{2+} \mathrm{mg} / \mathrm{l}$ & $29-115.3$ & 150 & 50 & 125 & Nil \\
\hline $\mathrm{Ca}^{2+} \mathrm{mg} / \mathrm{l}$ & $96-216.1$ & 200 & 200 & 200 & $1(6)$ \\
\hline $\mathrm{Cl}^{-} \mathrm{mg} / \mathrm{l}$ & 394-823.4 & 250 & 250 & 250 & All \\
\hline $\mathrm{So}_{4}^{2-} \mathrm{mg} / \mathrm{l}$ & $260-658$ & 400 & 250 & 250 & $3(1,3,4)$ \\
\hline $\mathrm{HCO}_{3}{ }^{-} \mathrm{mg} / \mathrm{l}$ & $254-468$ & - & 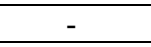 & 500 & Nil \\
\hline $\mathrm{TH} \mathrm{mg} / \mathrm{l}$ & $500.2-760.8$ & 500 & 500 & - & All \\
\hline
\end{tabular}

$(1,3, \ldots)=$ well number.

\subsection{Quality criteria for irrigation purpose}

Sodium and EC play a vital role in suitability of water for irrigation. Higher EC in water creates a saline soil. Harmful effects of irrigation water increases with the total salt concentration, irrespective of the ionic composition. Higher salt content in irrigation water causes an increase in soil solution osmotic pressure [18]. The salts apart from affecting the growth of plants also affect the soil structure, permeability and aeration which indirectly affect plant growth. Sodium adsorption ratio (SAR), ratio of dissolved sodium as $\% \mathrm{Na}$, or residual sodium carbonate (RSC) might equally be used for calculating a value which can be utilized as an index of ground water suitability for irrigation purposes [19].

\subsubsection{Total Dissolved Solids (TDS)}

Salts of calcium, magnesium, sodium, potassium present in the irrigation water may prove to be injurious to plants. When present in excessive quantities, they reduce the osmotic activities of the plants and may prevent adequate aeration. The TDS values of the study area ranged from 1452 to $2701 \mathrm{mg} / \mathrm{L}$. They are generally 
very high values and according to Robinove et al. [20], it can be classified (88.8\%) of the water samples as good to injurious for irrigation and $11.2 \%$ as unsatisfactory for irrigation, table 4 .

\subsubsection{Sodium Absorption Ratio (SAR)}

SAR is the most commonly used for evaluating groundwater suitability for irrigation purposes [20]. It is normally expressed as Na content or alkali hazard which is normally expressed in SAR [21]. SAR is expressed as follows, [22]:

$$
\mathrm{SAR}=\mathrm{Na}^{+} / \sqrt{ }\left(\mathrm{Ca}^{+2}+\mathrm{Mg}^{+2}\right) / 2
$$

where the ion concentrations are expressed in meq/l, as shown above, SAR values in irrigation waters have a close relationship with the extent to which $\mathrm{Na}$ is absorbed by soils. If water used for irrigation is high in $\mathrm{Na}$ and low in $\mathrm{Ca}$, the ion exchange complex may become saturated with $\mathrm{Na}$, which destroys soil structure because of dispersion of clay particles. As a result, the soil tends to become deflocculated and relatively impermeable. Such soils become very difficult to cultivate. The total concentrations of soluble salts in irrigation water can be classified as low (S1: < 10), medium (S2: 10--8), high (S3: 18-26) and very high (S4: > 26) [22]. The zones (S1-S4) have the value of EC less than $250 \mu \mathrm{S} / \mathrm{cm}$, $250-750 \mu \mathrm{S} / \mathrm{cm}, 750-2250 \mu \mathrm{S} / \mathrm{cm}$ and more than $2250 \mu \mathrm{S} / \mathrm{cm}$ respectively. The US salinity lab's diagram [1] is used widely for rating irrigation waters, where SAR is plotted against EC. The analytical data plot is shown in fig. 7.

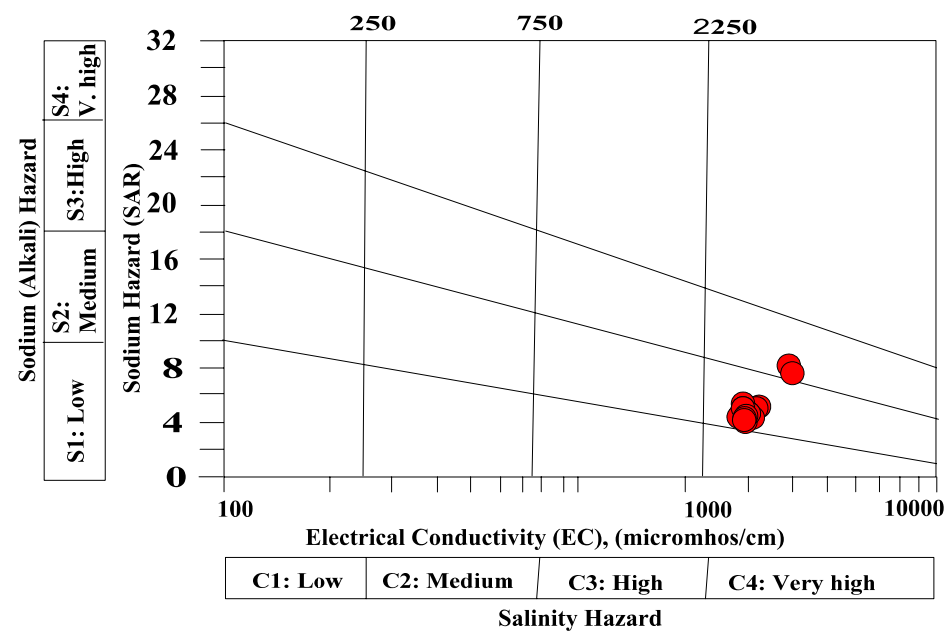

Figure 7: $\quad$ Salinity diagram of groundwater samples from the study area.

The SAR values range between 4.15 and 8.23 in the study area, where $11 \%$ of samples fall in C4-S3 classes and 89\% of samples fall in C4-S2 classes of USDA. The diagram in fig. 7 indicates very high salinity/ high sodium, and very high salinity/medium sodium type, respectively. 


\subsubsection{Soluble Sodium Percentage}

Sodium Percentage $(\mathrm{Na} \%)$ is the ratio of $\mathrm{Na}$ in epm in water to total cations epm multiplied by 100 . Irrigation water with $\mathrm{Na} \%>60$ may result in accumulation and possibly a deterioration of soil structure, infiltration, and aeration [23]. The values of collected water samples ranged from 60.1 to $72.2 \%$ with an average 63.9 . The $\mathrm{Na} \%$ and EC is important to categorize groundwater samples with respect to suitability as irrigation water. Wilcox [24] used percentage sodium and electrical conductance in evaluating the suitability of groundwater for irrigation. Wilcox diagram showing the position of the water samples is represented by fig. 8 . The diagram illustrates that $11 \%$, of the samples fall in the field of unsuitable and $89 \%$ fall in the field of doubtful to unsuitable for irrigation, table 4 .

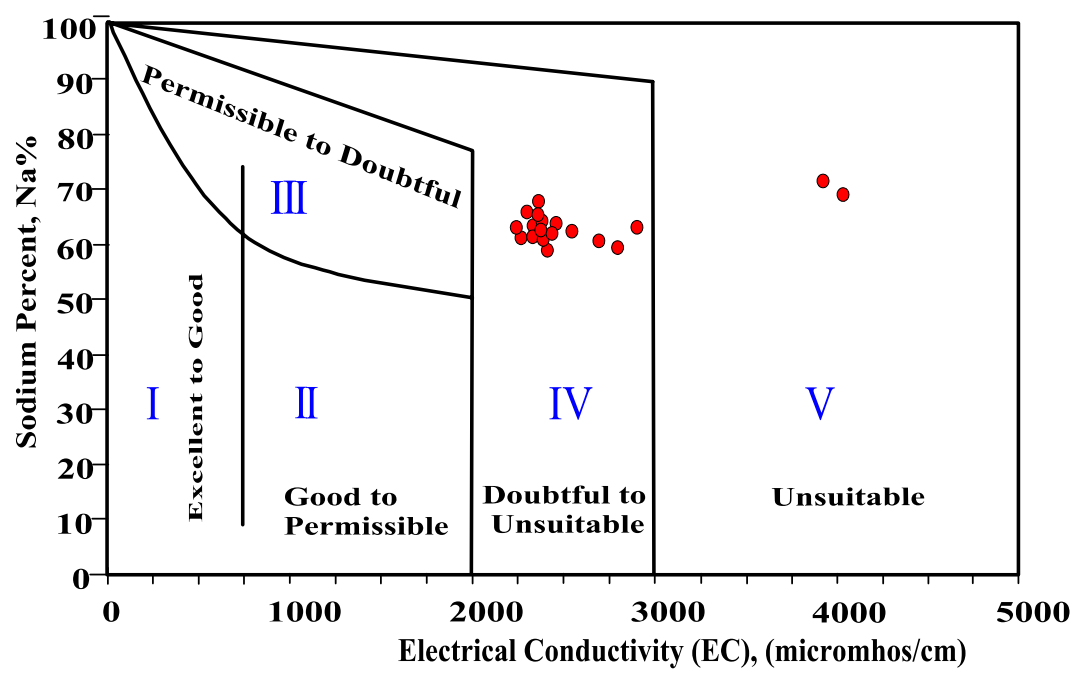

Figure 8: Position of water samples on the Wilcox plots.

\subsubsection{Residual Sodium Carbonate (RSC)}

Residue Sodium Carbonate (RSC) is a valuable parameter that has a great influence on the suitability of irrigation water [25]. The RSC significantly influence the $\mathrm{pH}, \mathrm{EC}$ and SAR of irrigation water. The samples of the study area have RSC ranged from -9.31 to -5.13 . With respect to RSC values, all the groundwater samples of the study area can be classified as "Good" for irrigation since all the values are less than 1.25 (table 4).

\subsubsection{Permeability Index (PI)}

The soil permeability is affected by long term use of irrigation water. It is influenced by sodium, calcium, magnesium and bicarbonate contents of soil. Doneen [26] has evolved a criterion for assessing the suitability of water for irrigation based on Permeability Index (PI):

$$
\mathrm{PI}=\left[\left(\mathrm{Na}^{+}+\sqrt{ } \mathrm{HCO}_{3}^{-}\right) /\left(\mathrm{Na}^{+}+\mathrm{Ca}^{+2}+\mathrm{Mg}^{+2}\right)\right] \mathrm{X} 100
$$


where all, ionic concentrations are expressed in (epm) [26]. The samples of the study area have PI ranged from 54.6 to $67.7 \%$. With respect to PI values, all the groundwater samples in the study area can be designated as class III (40-80\%) implying that the water is injurious quality for irrigation purposes with $75 \%$ or more of maximum permeability (table 4).

Table 4: Table Classification of irrigation water in Kiklah aquifer.

\begin{tabular}{|c|c|c|c|c|c|c|}
\hline Param. & Min & Max & Mean & Category & No of Sample & Water Class \\
\hline \multirow{5}{*}{$\mathrm{Na} \%$} & \multirow{5}{*}{60.1} & \multirow{5}{*}{72.2} & \multirow{5}{*}{63.9} & $<20$ & Nil & Excellent \\
\hline & & & & $20-40$ & Nil & Good \\
\hline & & & & $40-60$ & Nil & Permissible \\
\hline & & & & $60-80$ & 18 & Doubtful \\
\hline & & & & $>80$ & Nil & Unsuitable \\
\hline \multirow{5}{*}{$\begin{array}{c}\mathbf{E C} \\
\mu \mathrm{S} / \mathrm{cm}\end{array}$} & \multirow{5}{*}{2250} & \multirow{5}{*}{4033} & \multirow{5}{*}{2628} & $<250$ & Nil & Excellent \\
\hline & & & & $250-750$ & Nil & Good \\
\hline & & & & $750-2000$ & Nil & Permissible \\
\hline & & & & $2000-3000$ & 16 & Doubtful \\
\hline & & & & $>3000$ & $2(1,3)$ & Unsuitable \\
\hline \multirow{4}{*}{ SAR } & \multirow{4}{*}{4.15} & \multirow{4}{*}{8.23} & \multirow{4}{*}{5.13} & $<10$ & 18 & Excellent \\
\hline & & & & $10-18$ & Nil & Good \\
\hline & & & & $18-26$ & Nil & Fair \\
\hline & & & & $>26$ & Nil & Poor \\
\hline \multirow{3}{*}{ RSC } & \multirow{3}{*}{-9.3} & \multirow{3}{*}{-5.1} & \multirow{3}{*}{-6.9} & $<1.25$ & 18 & Good \\
\hline & & & & $1.25-2.50$ & Nil & Medium \\
\hline & & & & $>2.50$ & Nil & $\mathrm{Bad}$ \\
\hline \multirow{4}{*}{ PI\% } & \multirow{4}{*}{54.6} & \multirow{4}{*}{67.7} & \multirow{4}{*}{59.9} & $<20$ & Nil & Excellent \\
\hline & & & & $20-40$ & Nil & Good \\
\hline & & & & $40-80$ & 18 & Injurious \\
\hline & & & & $>80$ & Nil & Unsatisfactory \\
\hline \multirow{3}{*}{$\begin{array}{c}\text { TDS } \\
(\mathrm{mg} / \mathrm{l})\end{array}$} & \multirow{3}{*}{1452} & \multirow{3}{*}{2701} & \multirow{3}{*}{1700} & $<1000$ & Nil & Excellent \\
\hline & & & & $1000-2000$ & 16 & Good \\
\hline & & & & $>2000$ & $2(1,3)$ & Injurious \\
\hline \multirow[b]{2}{*}{ MAR \% } & \multirow[b]{2}{*}{$\begin{array}{c}18.0 \\
3\end{array}$} & \multirow[b]{2}{*}{52.7} & \multirow[b]{2}{*}{46.1} & $<50$ & 13 & Suitable \\
\hline & & & & $>50$ & $\mathbf{5}(2,9,11,14,15)$ & Unsuitable \\
\hline
\end{tabular}

\subsubsection{Magnesium Adsorption Ratio (MAR)}

Magnesium content of water is considered as one of the most important qualitative criteria in determining the quality of water for irrigation. Generally, calcium and magnesium maintain a state of equilibrium in most waters. More magnesium in water will adversely affect crop yields as the soils become more saline [28]. The values of the magnesium adsorption ratio of deep groundwater in the study area varies from $18.03 \%$ to $52.7 \%$ indicating that five wells are above the acceptable limit of $50 \%$ [29]. The waters are therefore, $27.8 \%$ of the samples considered unsuitable. This is because high magnesium adsorption ratio causes a harmful effect to soil when it exceeds $50 \%$. However, $72.2 \%$ of the samples were found suitable for irrigation. 


\section{Conclusions}

Groundwater quality of deep artesian groundwater (Kiklah aquifer) in Wadi Baye area, Middle Region, Libya, was analyzed to classify the groundwater into different categories for the drinking and irrigation purposes. The hydrochemistry of major-ions $\left(\mathrm{K}^{+}, \mathrm{Na}^{+}, \mathrm{Mg} 2+, \mathrm{Ca}^{2+}, \mathrm{Cl}^{-}, \mathrm{SO}_{4}{ }^{2-}, \mathrm{HCO}_{3}{ }^{-}\right.$was used to constrain the hydrochemical characteristics of the groundwater. The results show that the values of total dissolved solids $(<1452 \mathrm{mg} / \mathrm{L})$, electrical conductivity $(<2250 \mu \mathrm{S} / \mathrm{cm})$, soluble sodium percentage (60.1 to $72.2 \%$ ), permeability index (59.6 to $67.7 \%$ ), residual sodium bicarbonate $(<1.25)$, sodium adsorption ratio $(<10)$ and magnesium adsorption ratio varies from $(18.03 \%$ to $52.7 \%)$. The results of hydrochemical analyses also indicate show that the most of water parameters are higher than the maximum standard limits, according to Libyan Standards (1993), WHO (1983) and US Public Health Service (1975). The hydrochemical composition reflects the $\mathrm{Cl} \cdot \mathrm{SO} 4-\mathrm{Na} \cdot \mathrm{Ca}$ water type is recorded within the Wadi upstream area and another major water type is $\mathrm{Cl} \cdot \mathrm{SO} 4-\mathrm{Na}$. According to the important constituents' parameters affecting the water quality for irrigation such as the sodium adsorption ratio, sodium percentage ratio, residue sodium carbonate, permeability index and the magnesium hazard, most of the ground waters are classified as good, doubtful, good, injurious and $72.2 \%$ stable for irrigation respectively. In addition, the US Salinity Laboratory diagram illustrates that, most of the ground waters are located in the high salinity and medium sodium hazard zone(C4-S2), while the Wilcox diagram illustrates that $11 \%$, of the groundwater samples fall in the field of unsuitable and $89 \%$ fall in the field of doubtful to unsuitable for irrigation.

In conclusion, overall, the groundwater can be classified with few exceptions as suitable for irrigation under certain conditions such as good management, good drainage system, deep ground to keep soil salt balance and highly salt tolerant plants. However, it is recommended that water drawn from such sources should be purified of excess elements well before being used for drinking and other domestic uses. It also should be excluded wells numbered as 1, 3, 4, and 6 from the domestic and drinking use. Also it is recommended that the water should be not used directly after pumping.

\section{Acknowledgements}

We would like to thank The Man-made River Water Utilization Authority; Middle Region for the opportunity they gave us to do this research. Also we would like to thanks Al Kardabia company for giving us the important data to accomplish this paper.

\section{References}

[1] US Salinity Laboratory Staff, Diagnosis and Improvement of Saline and Alkali Soils. In: USDA Agric Handbook No. 60. U.S Government Printing Office, Washington, D.C., 1954. 
[2] Keller W.D., Drinking water, A geochemical factor in human health, Geological Society of America Bulletin, March, v. 89, no. 3, pp. 334-336, 1978.

[3] Jouyban Z., The Effects of Salt stress on plant growth, Technical Journal of Engineering and Applied Sciences, ISSN 2051-0853, 2012.

[4] Peiyue L., Qian W. \& Jianhua W., Groundwater suitability for drinking and agricultural usage in Yinchuan area china, International journal of environmental science, v. 1-6, pp. 1241-1249, 2011.

[5] Anim A.K., Duodu G.O. \& Ahialey E.K., Assessment of surface water quality: The perspectives of the Weija dam, Ghana. International Journal of Chemistry, 3-2., pp. 32-39, 2011.

[6] Oladeji O.S., Adewoye A.O., \& Adegbola A.A., Suitability assessment of groundwater resources for irrigation around Otte Village, Kwara State, Nigeria, Journal of Applied Sciences and Engineering Research, Vol. 1, Issue 3, 2012.

[7] IRC, Geological Map of Libya (Scale 1:1,000,000), Industrial Research Centre (IRC), Geological Researches \& Mining Department, 1985.

[8] Gefli, Groupement D'Etude Francais En libye Siege Social. Survey for the development of the central wadi zone and Gulf of Sirte, 8 rue Jean Goujon 75008 Paris, 1973.

[9] Meteorological Station, Sirte, 2010, Data collected from 1980 to 2008.

[10] Basher M.H., Yang Y. \& Falconer R., Fate and transport of nutrients in groundwater in the northern coastal area of Libya, PhD thesis, School of Engineering, Cardiff University. 2011.

[11] APHA, Standard methods for the examination of water and waste water, American Health Association, 14 ${ }^{\text {th }}$. Ed. Washington, p. 759, 1975.

[12] Libyan National Center for specifications and Drinking water standards. No. 82, 1992.

[13] World Health Organization (WHO), Guidelines to drinking water quality, Geneva, p. 186, 1983.

[14] US Public Health Service, Drinking Water Standards Public. 969. Washington, D.C. p. 61, 1975.

[15] Hayashi M., Temperature-electrical conductivity relation of water for environmental monitoring and geophysical data inversion. Environmental Monitoring and Assessment, 96, 119-128, 2004.

[16] Lloyd J.W. \& Heathcote J.A., Natural Inorganic Hydrochemistry in Relation to Groundwater. Oxford Press Oxford, pp. 296, 1985.

[17] Piper A.M., A graphical procedure in the geochemical interpretation of water analysis, Am Geophys Union Trans, Vol. 25, No. 1944, pp. 914-928, 1944.

[18] Thorne, D.W., \& Peterson, H.B., Irrigated soils, Their Fertility and Mangement. 2ed. New York: Blakiston, 1954.

[19] Shaki A.A. \& Adeloye, A.J., Evaluation of quantity and quality of irrigation water at Gadowa irrigation project in Murzuq basin, southwest Libya, Vol. 84, No. 1-2, 16.07., pp. 193-201, 2006. 
[20] Robinove C.J., Longfort R.H. \& Brook J.W., Saline Water resource of North Dakota US Geol., Water Supply Paper, 1428, p. 72, 1958.

[21] Ayers R.S. and D.W., Westcot, Water quality for agriculture FAO irrigation and drain. Paper No 29(1): 1-109, 1985.

[22] Richards, L.A., Diagnosis and improvement of saline and alkali soils. US Department of Agricultural Handbook, Vol. 60, Washington D.C., 1954. USA, p. 160.

[23] Hem, J.D. Study and Interpretation of the Chemical Characteristics of Natural water. USGS Water Supp. Paper no. 2254, p. 263, 1991.

[24] Wilcox L.V., The quality of water for irrigation use vol. 40. US Department of Agriculture Technology Bulletin 962, Washington DC, 1948.

[25] Gupta, S.K. \& Gupta, I.C., Management of Saline Soils and Water. Oxford and IBH publication Co., New Delhi, India, pp. 399, 1987.

[26] Doneen L.D. The influence of crop and soil on percolating waters. Proceeding of Biennial Conference on Groundwater Recharge, pp. 156-163, 1962.

[27] Ayers R.S. \& Westcot D.W., Water Quality for Agriculture. Food and Agriculture Organization of the United Nations, Rome, 1976.

[28] Joshi, D.M., Kumar A. \& Agrawal N., Assessment of the irrigation water quality of River Ganga in Haridwar District India. J. Chem., 2(2): 285-292, 2009.

[29] Ayers, R.S. \& Westcot D.W., Water quality for agriculture FAO irrigation and drain. Paper No 29(1): 1-109, 1985. 